\title{
SPATIAL FIRE MODELING IN MKUZE GAME RESERVE: A CASE STUDY
}

\author{
STEPHEN G. BERJAK ${ }^{1}$ AND JOHN W. HEARNE ${ }^{2}$ \\ ${ }^{1}$ Department of Applied Mathematics, University of Stellenbosch, \\ Private Bag X1, MATIELAND, 7602, South Africa \\ Email: sberjak@dip.sun.ac.za \\ ${ }^{2}$ Department of Mathematics and Statistics, RMIT University, GPO Box 2476V, \\ Melbourne, Victoria 3001, Australia \\ Email: john.hearne@rmit.edu.au
}

\begin{abstract}
Controlled burning is a necessary and regular activity in Mkuze Game Reserve, South Africa. Predicting the rate and extent of fire spread in controlled burning operations is, therefore, an important management objective. In this paper we evaluate a cellular automaton model for fire spread in terms of this objective using empirical data for two case studies in Mkuze Game Reserve. Incorporating data relating to factors such as temperature reduction in the early evening, subsequent dew formation and increased fuel moisture content, the model was found to closely resemble the observed fire behaviour.
\end{abstract}

Keywords: Fire model, cellular automaton, spatial heterogeneity, Mkuze Game Reserve, savanna system.

\section{INTRODUCTION}

Mkuze Game Reserve (MGR) is a 37 000ha reserve located in northern KwaZulu-Natal (KZN), South Africa (Figure 1), managed by the KZN Wildlife. The region is characterised by an exceptionally high bio-diversity, which is attributed to the high spatial heterogeneity at the landscape level (Goodman, 1990). To conserve bio-diversity in MGR, specific actions have been identified and incorporated into the framework of a reserve management plan. In particular, spatial heterogeneity within the reserve may be practically manipulated using several management tools, including fire and the distribution of water and mega-herbivore populations (Goodman, 1990). 


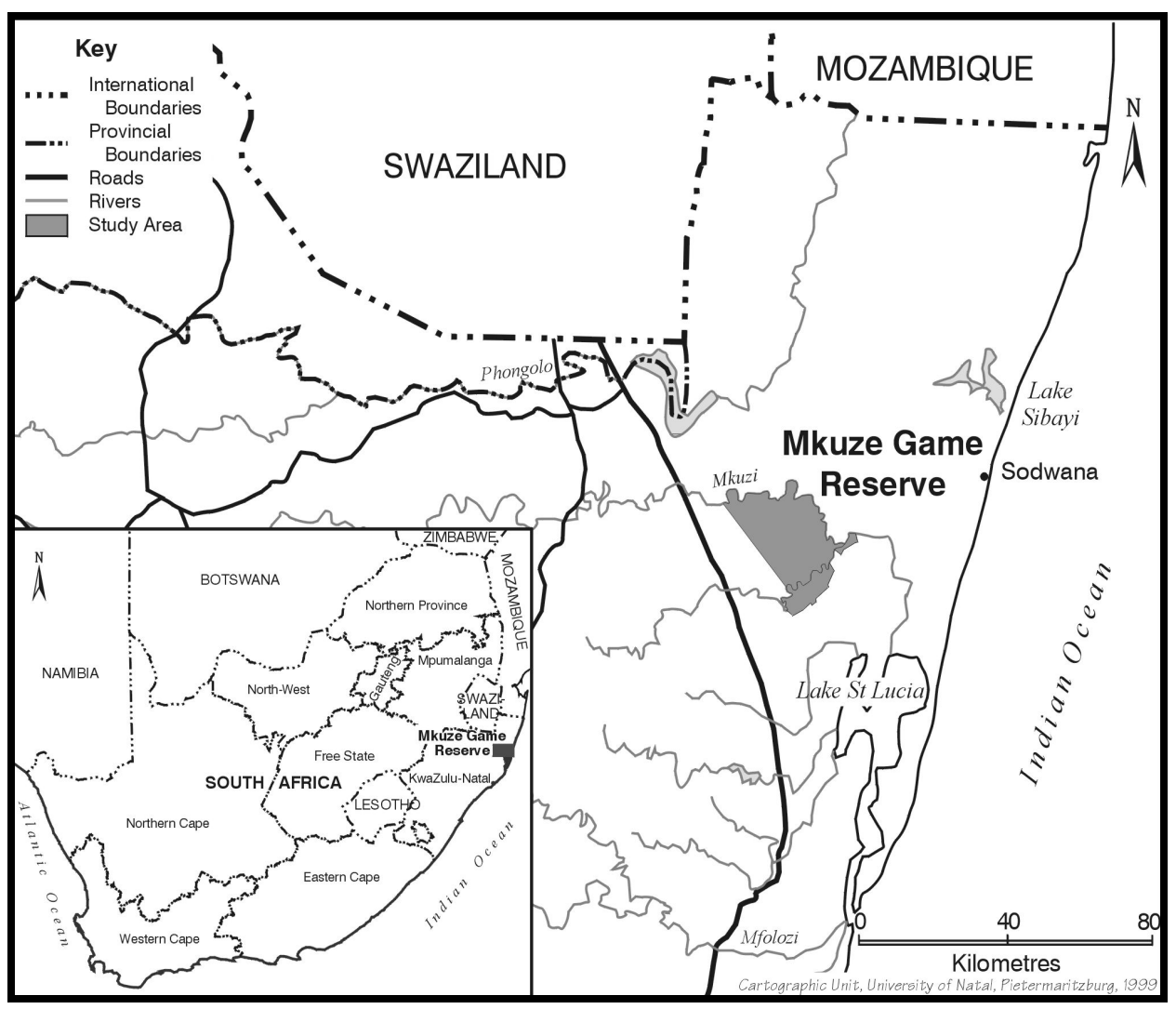

Figure 1. Site map of MGR in northern KwaZulu-Natal, South Africa.

Fire is extensively used in the management of ecosystems worldwide, primarily because it is a relatively inexpensive option by which the vegetation of an area can be manipulated (Bond \& van Wilgen, 1996). In savanna ecosystems, which are characterised by the coexistence of grasses and trees, the balance between grass and trees depends on a complex set of factors, most notably, water, herbivory, fire, soil texture and nutrients (Higgins, Bond \& Trollope, 2000). The major goals of management have shifted from attempts to utilise fire to achieve a stable vegetation composition, to recognising that these ecosystems are in constant flux. Fire is a major form of disturbance that helps to maintain a state of flux, thereby conserving biodiversity (van Wilgen, Biggs \& Potgieter, 1998). Grass fires occur in savanna ecosystems because grass production in the wet season is followed by an extended dry season, thereby leading to a continuous fuel covering in which a ready source of ignitions exist. Higgins, Bond \& Trollope (2000) hypothesise that savannas exist under conditions where fires are intense enough to limit the recruitment rates of trees, but not too intense to prevent recruitment (as in grasslands) or so mild as to not limit recruitment (as in surface fires in forests). 
Deciding how, where, and when to apply fire depends on the management objectives of the area concerned and the constraints that apply to that case. There are many diverse management objectives that influence the type of fire applied in a particular ecosystem (Bond \& van Wilgen, 1996), such as the reduction of fire hazard by applying frequent fires under mild conditions, thereby reducing the fuel load and thus the intensity and frequency of accidental or arson fires. Forestry operations use fire for site preparation, fuel reduction, and manipulation of the composition of forest stands through inducing selective mortality in firesensitive species. Fire can be used in controlling invasion by undesirable plants. In livestock production, fire is used to achieve a plant composition that ensures optimal foraging conditions. Fire is often applied to influence the hydrological cycle e.g. to enhance water yield from catchments or to prevent erosion. Fire may be used to stimulate an out-of-season flush of growth. Conservation aims are often met by applying fire, particularly in ecosystems where fire-dependent species and communities are involved. Fire may be used in nature reserves and other recreation areas to create habitats suited to certain game species and to induce game to graze otherwise non-preferred areas.

The primary management objectives for MGR is to maintain or enhance spatial heterogeneity, to ensure fodder flow to large mammals, to retard woody plant growth, and to reduce the risk of accidental or arson fires that will threaten the survival of plant species or destroy the composition or structure of a priority vegetation community (Goodman, 1990). Since both lightning and man-induced fire is believed to have played a major role in the development of the vegetation in MGR, fire is applied as a management tool with the intention that natural processes are allowed to prevail over those that are obviously artificial. For this reason no attempt is made to apply a rigidly defined burning programme with specific frequencies and block boundaries (Goodman, 1990). Fires are simply ignited at a point and allowed to determine their own burn pattern and extents, which, conceptually, emulates the type of fire regime under which the land and all its biota have evolved. The decision to ignite vegetation must consider whether the resultant fire will achieve the desired effect, while still remaining in the required limits of safety. To predict the potential behaviour of a fire, the many factors influencing fire behaviour need to be integrated (Bond \& van Wilgen, 1996). This can be done in two ways. The first is traditional burning practices based on experience only, which is the existing policy at MGR (Goodman, 1990). The second approach is to supplement field experience with models of fire behaviour. In this regard, we evaluate the predictive ability of 
a cellular automaton model for spatial fire spread (Berjak \& Hearne, 2002) for two case studies in MGR.

\section{MODEL DESCRIPTION}

The fundamental properties of a cellular automaton (CA) model are the definition of the state of a cell and the local rule that updates this state from one time interval to the next. Suppose that the physical landscape is represented by a matrix of identical square cells, where each cell forms a single cell in the CA lattice. The state $S_{i, j}^{t}$ of the $(i, j)$-th cell at time $t$ is defined as a function $f$ of the heat dynamics of the cell, such that

$$
S_{i, j}^{t}=f\left(\frac{H_{t}}{H_{0}}, t\right),
$$

where $H_{t}$ denotes the total heat received from neighbouring cells by the $(i, j)$-th cell at time $t$ and $H_{0}$ is the total heat required to ignite the unburned fuel (calculated at time $t=0$ ). Hence the state of the $(i, j)$-th cell is defined as being:

1. Unburned if the fuel in the cell needs additional heat for combustion, i.e. $H_{t}<H_{0}$.

2. Burning if sufficient heat has been received by the unburned fuel to result in combustion, i.e. $H_{t} \geq H_{0}$.

3. Burned if the heat generated by the burning fuel in the cell is insufficient to maintain the combustion process.

The CA local rule determines the influence of the state of a particular cell on some or all of the immediately adjacent neighbours. The state of the $(i, j)$-th cell at time $t+1$ was assumed to depend on $S_{i, j}^{t}$ and the rate of fire spread $R_{k, l}^{t}$ from an immediately adjacent neighbouring cell to the $(i, j)$-th cell, where $(k, l)=\{(i-1, j-1),(i-1, j),(i-1, j+1),(i, j-1),(i, j+1),(i+1, j-1),(i+1, j)$, $(i+1, j+1)$,$\} , such that$

$$
S_{i, j}^{t+1}=f\left(S_{i, j}^{t}, R_{i-1, j-1}^{t}, R_{i-1, j}^{t}, R_{i-1, j+1}^{t}, R_{i, j-1}^{t}, R_{i, j+1}^{t}, R_{i+1, j-1}^{t}, R_{i+1, j}^{t}, R_{i+1, j+1}^{t}\right) .
$$

The rate of fire spread is $0 \mathrm{~m} \cdot \mathrm{min}^{-1}$ in the case of an unburned cell or a burned cell. In the case of a burning cell, the rate of fire spread from the $(i, j)$-th cell to each of its eight neighbouring cell is defined by the vector field 


$$
\tilde{R}_{i, j}=R_{0} \cdot\left[\begin{array}{l}
\left(\phi_{f} \cdot \phi_{w} \cdot \phi_{s}\right)_{i-1, j} \\
\left(\phi_{f} \cdot \phi_{W} \cdot \phi_{s}\right)_{i, j+1} \\
\left(\phi_{f} \cdot \phi_{W} \cdot \phi_{s}\right)_{i+1, j} \\
\left(\phi_{f} \cdot \phi_{W} \cdot \phi_{s}\right)_{i, j-1} \\
\left(\phi_{f} \cdot \phi_{W} \cdot \phi_{s}\right)_{i-1, j-1} \\
\left(\phi_{f} \cdot \phi_{W} \cdot \phi_{s}\right)_{i-1, j+1} \\
\left(\phi_{f} \cdot \phi_{W} \cdot \phi_{s}\right)_{i+1, j+1} \\
\left(\phi_{f} \cdot \phi_{W} \cdot \phi_{s}\right)_{i+1, j-1}
\end{array}\right],
$$

where $R_{0}$ is the rate of fire spread in the absence of wind and topographic factors, and $\phi_{f}, \phi_{w}$ and $\phi_{s}$ are factors incorporating the effects of spatial (fuel) heterogeneity, wind (speed and direction) and topography respectively on the rate of fire spread. Hence the product $R_{0}\left(\phi_{f} . \phi_{w} . \phi_{s}\right)_{k, l}$ denotes the component of the vector velocity field for the rate of fire spread from the $(i, j)$-th cell to a neighbouring $(k, l)$-th cell.

\subsection{RATE OF FIRE SPREAD}

The rate of fire spread $R_{0}\left(\mathrm{~m} \cdot \mathrm{min}^{-1}\right)$ is determined, via the Rothermel (1972) fire spread model, by assigning each cell parameters describing its fuel characteristics (summarised by a fuel model containing values for the fuel load, fuel bed depth, surface area to volume ratio, extinction moisture content and heat content), moisture content and elevation, from which

$$
R_{0}=\frac{I_{r} \xi}{\rho_{b} \varepsilon Q_{i g}}
$$

is calculated, where $I_{r}$ is the reaction intensity $\left(\mathrm{kg} \cdot \mathrm{m}^{-2}\right), \xi$ is the propagating flux ratio $\left(\mathrm{kJ} . \mathrm{m}^{-}\right.$ $\left.{ }^{2} \cdot \mathrm{min}^{-1}\right), \rho_{b}$ is the fuel bulk density $\left(\mathrm{kg} \cdot \mathrm{m}^{-3}\right), \varepsilon$ is the (dimensionless) effective heating number, and $Q_{i g}$ is the heat of pre-ignition $\left(\mathrm{kJ}^{\mathrm{kg}} \mathrm{kg}^{-1}\right)$. Further details on the formulation of (2.3) are given in Burgan and Rothermel (1984).

\subsection{FUEL HETEROGENEITY}

The effect of spatial (fuel) heterogeneity is incorporated into the CA model by analysing the heat dynamics of the respective burning and unburned adjacent fuel types. A fire may spread from one particular fuel type to another if the heat received by the unburned fuel is sufficient to cause ignition, such that 


$$
\phi_{f}=\frac{\left(H_{c}\right)_{\alpha}}{\left(H_{0}\right)_{\beta}}=\left\{\begin{array}{ll}
1 & \text { if }\left(H_{c}\right)_{\alpha} \geq\left(H_{0}\right)_{\beta} \\
0 & \text { otherwise }
\end{array},\right.
$$

where $\left(H_{c}\right)_{\alpha}$ represents the amount of heat produced by fuel $\alpha$ that reaches the unburned fuel and $\left(H_{0}\right)_{\beta}$ is a measure of the total heat required to ignite fuel $\beta$. Hence a fire may spread from a burning $(i, j)$-th cell, with fuel type $\alpha$, to a neighbouring unburned $(k, l)$-th cell, with fuel type $\beta$ ), if the (binary) combustibility multiplier $\left(\phi_{f}\right)_{k, l}$ is equal to 1 .

\subsection{TOPOGRAPHIC EFFECTS}

Slope has a considerable influence on the rate of spread, especially in the initial stages of a fire (Luke \& McArthur, 1978). If a fire burns up a slope, then the angle between the flame and the unburned fuel is reduced, which leads to an increase in the degree of preheating of the unburned fuel immediately in front of the flames, thereby resulting in an increase in the forward rate of spread (Burgan \& Rothermel, 1984). Conversely, the angle increases for a fire spreading down slope and the radiant heat transfer decreases, causing a decrease in the rate of spread. The slope factor $\phi_{s}$ utilised in the CA model was based on Cheney's (1981) proposition for the effect of topography on the rate of fire spread, such that

$$
\phi_{s}=\exp \left(\alpha \theta_{s}\right)
$$

where $\alpha$ is a constant equal to 0.0693 ; and $\theta_{s}$ is the slope angle. Since each cell contains a parameter for its elevation, the value of $\theta_{s}$ is determined by calculating the difference in height between any two neighbouring cells and dividing by the horizontal distance between the two cells.

\subsection{WIND EFFECTS}

Wind is generally viewed as affecting heat transfer from a flame to unburned fuel downwind of the flame primarily by changing the angle between the flame relative to the fuel. Wind increases radiant heat transfer for headfires because the flame is tilted toward the unburned fuel and decreases radiant heat transfer for backfires because the flame is tilted away from the unburned fuel (Burgan \& Rothermel, 1984). The wind factor $\phi_{w}$ was assumed to be an exponential function of the flame angle $\theta_{f}$, such that

$$
\phi_{w}=\exp \left(\beta \theta_{f}\right)
$$


where $\theta_{f}$, was calculated using the Weise and Biging (1996) flame height model, and the value of the constant $\beta=0.0576$ was estimated using data for 10 field-scale experimental fires conducted at the Hluhluwe \& Umfolozi Game Reserves in northern KwaZulu-Natal (Wills, 1987).

Wind direction is restricted in the model to the eight major compass directions. The rate of fire spread in the direction of the wind is modified according to the flame angle $\theta_{f}$. The rate of fire spread in the opposite direction to the wind is adjusted by setting flame angle to $-\theta_{f}$. In all other directions, the flame angle $\theta_{f}$ is set equal to 0 .

\subsection{CA LOCAL RULE}

It follows from the preceding subsections that the general form of the spatial fire spread model for a fire spreading from the $(i, j)$-th cell to a neighbouring $(k, l)$-th cell is given by

$$
\tilde{R}_{i, j}=R_{0} \exp \left(\alpha\left(\theta_{s}\right)_{k, l}+\left(\beta \theta_{f}\right)_{k, l}\right)\left(\phi_{f}\right)_{k, l}
$$

If the side of each cell is of length $a$, then the CA local rule for updating the cells (for a discrete time interval $\Delta t$ ) in the lattice is given by

$$
\begin{aligned}
S_{i, j}^{t+1}=S_{i, j}^{t}+ & \left\{\left(\frac{1}{a}\right)\left(R_{i-1, j}^{t}+R_{i, j-1}^{t}+R_{i, j+1}^{t}+R_{i+1, j}^{t}\right)\right\} \Delta t+ \\
& 0.17\left\{\left(\frac{1}{\sqrt{2} a}\right)\left(R_{i-1, j-1}^{t}+R_{i-1, j+1}^{t}+R_{i+1, j-1}^{t}+R_{i+1, j+1}^{t}\right)\right\} \Delta t
\end{aligned},
$$

where the factor 0.17 , representing the relative proportion of heat received by the $(i, j)$-th cell from a diagonal neighbour compared to an adjacent neighbour, is taken from the (mathematical derivation) in Berjak \& Hearne (2002).

\section{DATA COLLECTION}

Basic inputs to the model include a description of the fuel, fuel moisture content for each size class (live and dead), wind speed and slope. Spatial information for fuels, topography, ignition points and fire boundaries were captured into a Geographic Information System (GIS) from a variety of sources including Landsat Thematic Mapper (TM) satellite imagery, aerial photographs and orthophotographs and existing GIS layers. Broad scale climatological information at the commencement of a burn was recorded, on the day of the event, by reserve management. 


\subsection{FUEL CLASSIFICATION}

For ease of use, fuel descriptions are usually assembled into fuel models, which may be selected as required (Anderson, 1982). The most important fuel descriptors include fuel bed depth, fuel load in each size class and surface area to volume ratio of the fine dead fuel. The fire spread model is then applied to a landscape by classifying natural fuels into various types according to the fuel models.

Fuel classification was performed using a Landsat TM satellite image, consisting of 7 distinct spectral bands, with a pixel size of $25 \times 25$ metres. The entire area of MGR was covered in a single scene that was taken prior to the burning season. The fuel layer was mapped to 13 fuel models developed by Anderson (1982), plus two non-fuel classes (Table 1), using a combined supervised/unsupervised approach (Congalton, Green \& Teply, 1993; Thompson, 1993). Since these fuel models were developed specifically for fuel conditions in the United States, the MGR fuels were mapped to the fuel model that most closely resembled the on-site vegetation. Image classification was enhanced through the use of aerial photographs, taken in 1975 and 1999 respectively, and ancillary GIS data layers. The latter included a detailed vegetation coverage containing fields for vegetation physiognomy, floristics, sensitivity/conservation value, soils and geology (Goodman, 1990).

\begin{tabular}{|c|c|c|}
\hline Fuel Model/Class & Model Description & Hectares \\
\hline \multicolumn{3}{|c|}{ Grass and grass-dominated models } \\
\hline 1 & Short Grass & 6197 \\
\hline 2 & Timber (grass and understory) & 5175 \\
\hline 3 & Tall grass & 562 \\
\hline \multicolumn{3}{|l|}{ Chaparral and shrub fields } \\
\hline 4 & High pocosin, chaparral & 5046 \\
\hline 5 & Brush & 0 \\
\hline 6 & Dormant brush, hardwood slash & 1042 \\
\hline 7 & Southern rough, low pocosin & 1079 \\
\hline \multicolumn{3}{|l|}{ Timber Litter } \\
\hline 8 & Closed timber litter & 14 \\
\hline 9 & Hardwood litter & 792 \\
\hline 10 & Heavy timber litter and understory & 2942 \\
\hline
\end{tabular}




\begin{tabular}{lclc}
\hline Slash & 11 & Light logging slash & \\
& 12 & Medium logging slash & 0 \\
Non fuel & 13 & Heavy logging slash & 0 \\
& 14 & & 0 \\
& 15 & Water & 712 \\
& & Bare, non-flammable & 41 \\
\hline
\end{tabular}

Table 1. Fuel classification system for the MGR study area.

\subsection{TOPOGRAPHY}

Vector contours were digitised at 5-metre intervals using 1:10 000 scale orthophoto sheets covering MGR and mosaiced to form a single continuous topographic layer. A digital elevation model (DEM) ${ }^{1}$, with a pixel size of $25 \times 25 \mathrm{~m}$, was then generated by resampling the vector topographic coverage. The elevation recorded in each pixel in the DEM was then extracted and utilised in the implementation of the model.

\subsection{IGNITION POINTS AND FIRE BOUNDARIES}

The ignition points and the final extents of the fire were captured by the KZN Wildlife using Global Positioning Systems (GPS). Unfortunately, intermediate fire boundaries, recorded at regular time intervals, were not available. This information would be useful for further analysis of the model.

\subsection{FIRE RECORDS}

Fuel and environmental conditions, prior to ignition, were compiled, in the format of a handwritten fire record, by the fire manager. Fuel conditions are described in terms of a greenness index, mean fuel height, density and uniformity index. Environmental conditions contain broadly defined weather conditions e.g. cold morning/hot day. Wind speed is measured on the Beaufort scale (Table 2) and wind direction is recorded as being one of the eight major compass directions. The location, time and type of ignition, time of extinction and reason for burning are also documented in the fire record.

\footnotetext{
${ }^{1}$ A DEM is a raster, or grid, coverage in which each cell contains a value for its elevation.
} 


\begin{tabular}{|c|c|c|c|c|}
\hline \multirow{2}{*}{$\begin{array}{l}\text { Beaufort } \\
\text { Number }\end{array}$} & \multirow{2}{*}{ Term } & \multirow{2}{*}{ Description } & \multicolumn{2}{|c|}{ Wind Speed } \\
\hline & & & $\mathrm{km} / \mathrm{h}$ & knots \\
\hline 0 & Calm & Smoke rises vertically & $<1$ & $<1$ \\
\hline \multirow[t]{2}{*}{1} & Light air & Smoke drifts slowly; & & \\
\hline & & wind vanes not affected & $1-5$ & $1-3$ \\
\hline \multirow[t]{2}{*}{2} & Light breeze & Wind felt on face; leaves rustle; & & \\
\hline & & ordinary wind vanes move & $6-11$ & $4-6$ \\
\hline \multirow[t]{2}{*}{3} & Gentle breeze & Leaves and twigs in motion; wind & & \\
\hline & & extends light flag & $12-19$ & $7-10$ \\
\hline \multirow[t]{2}{*}{4} & Moderate breeze & Dust and loose paper raised; small & & \\
\hline & & branches move & $20-28$ & $11-16$ \\
\hline 5 & Fresh breeze & Small trees sway & 29- 38 & $17-21$ \\
\hline \multirow[t]{2}{*}{6} & Strong breeze & Large branches in motion; whistling & & \\
\hline & & heard in telephone wires & $39-49$ & $22-27$ \\
\hline \multirow[t]{2}{*}{7} & Near Gale & Whole trees in motion; inconvenience & & \\
\hline & & felt when walking against wind & $50-61$ & $28-33$ \\
\hline \multirow[t]{2}{*}{8} & Gale & Twigs broken off trees; progress of & & \\
\hline & & walkers impeded & $62-74$ & $34-40$ \\
\hline 9 & Strong gale & Branches broken off trees & $75-88$ & $41-47$ \\
\hline
\end{tabular}

Table 2. Beaufort scale for estimating wind velocity.

\section{MODEL IMPLEMENTATION}

\subsection{CASE 1: MAHLALA FIRE}

The Mahlala region of MGR was burned on the $28^{\text {th }}$ August 1997 to reduce the grass fuel load. The fire was ignited at $12 \mathrm{~h} 30 \mathrm{p} . \mathrm{m}$. in the presence of a light north-easterly breeze and extinguished at $22 \mathrm{~h} 00$ that same evening (Table 3 ).

\begin{tabular}{ccccc}
\hline Area & $\begin{array}{c}\text { Time of } \\
\text { Ignition }\end{array}$ & $\begin{array}{c}\text { Time of } \\
\text { Extinction }\end{array}$ & $\begin{array}{c}\text { Wind } \\
\text { Speed }\end{array}$ & $\begin{array}{c}\text { Wind } \\
\text { Direction }\end{array}$ \\
\hline \multirow{2}{*}{ Mahlala } & $28 / 08 / 97$ & $28 / 08 / 97$ & & \\
\hline
\end{tabular}

Table 3. Selected information from the fire record for Mahlala area of MGR. 
The area burned comprised grass and understory (fuel model 2). The lateral spread of the fire was restricted by hardwood litter (fuel model 9) and heavy timber litter and understory (fuel model 10) on either side of the grass. The impact of the various types of vegetation on the final extents of the fire is graphically apparent in Figure 2.

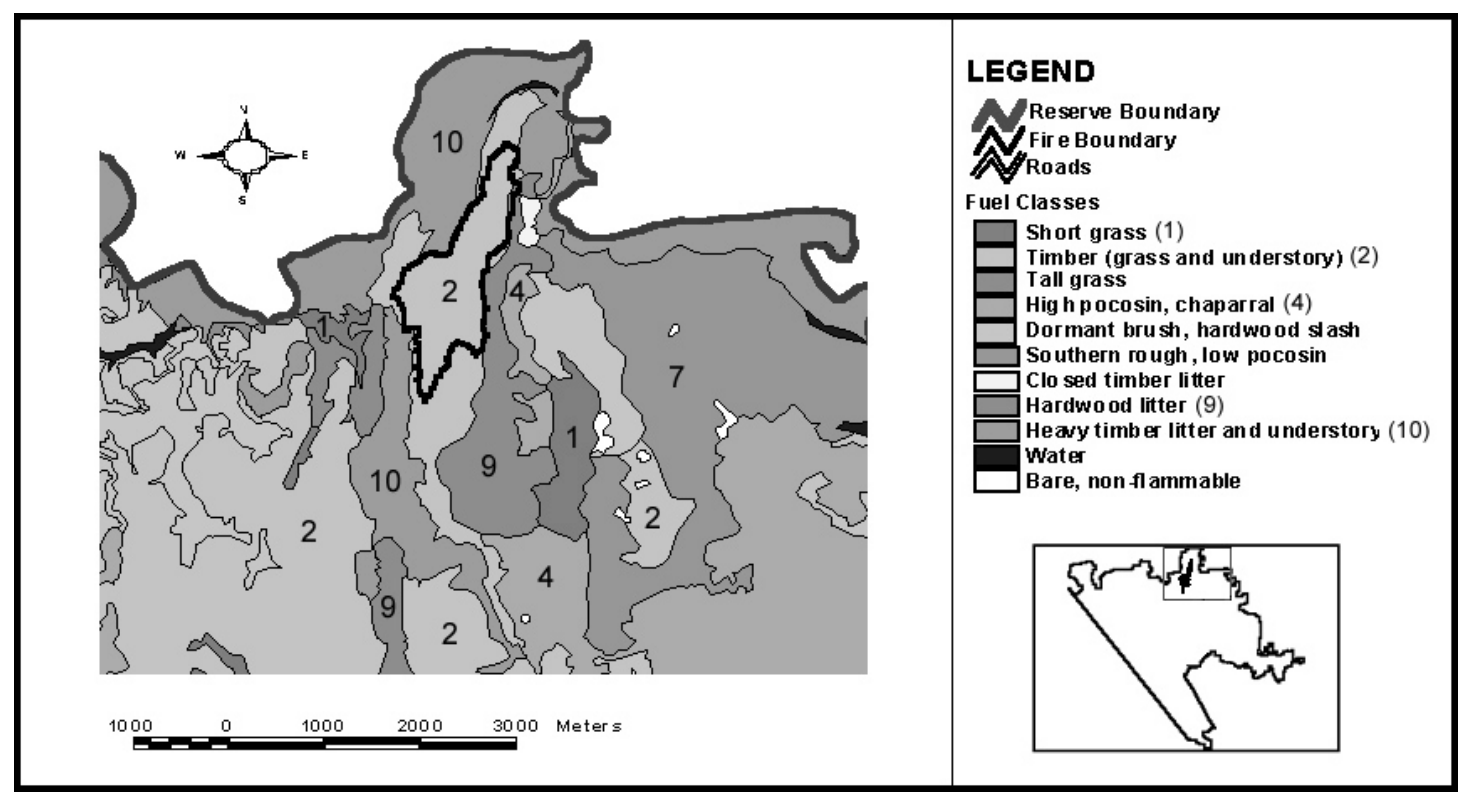

Figure 2. Map of fuel classes for the Mahlala fire.

The topography of the Mahlala region is characterised by a ridge with a long axis gradually downward slope in a north-east to south-west direction (Figure 3). The ridge, which forms a saddle feature, contains a number of peaks and valleys. The highest point within the observed fire boundary is the summit of a hill in the south-west, which has an elevation of $110 \mathrm{~m}$. In contrast, the lowest point has an altitude of approximately $65 \mathrm{~m}$. 


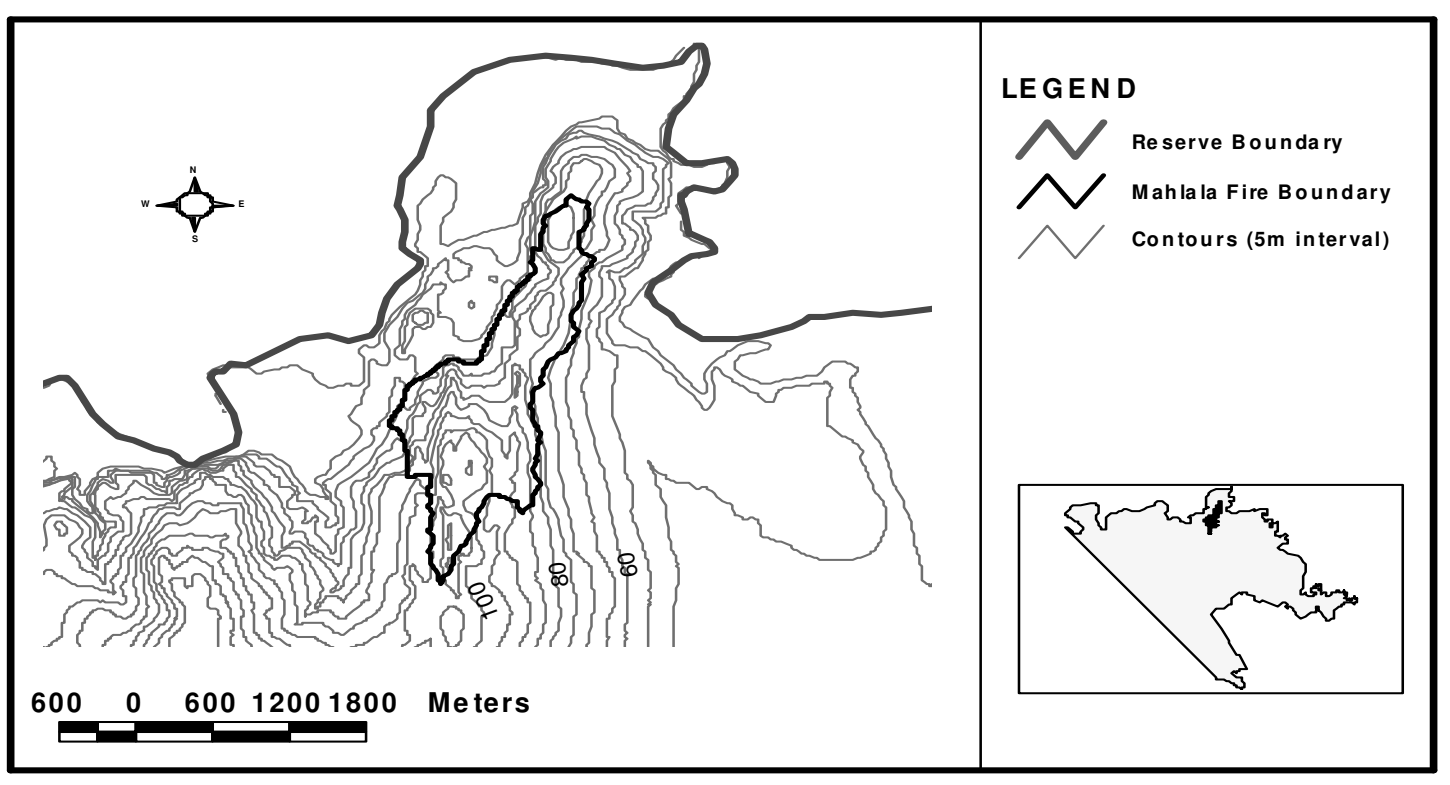

Figure 3. Map of contours at $5 \mathrm{~m}$ intervals for the Mahlala fire.

Figure 4 illustrates successive fire fronts produced by the simulation model after 1, 4, 6 and 8 hours respectively. The model was implemented using square grid cells with side length equal to 50 metres. Based on information in the fire record (in particular the fuel greenness index, environmental conditions, and time of ignition), the initial fuel moisture content of all (dead) fuels types was assumed to be $3 \%$ of the dry weight; live fuels were assumed to not contribute to the rate of fire spread.-The fire was propelled by a constant north-easterly breeze of $50 \mathrm{~m} \cdot \mathrm{min}^{-1}$.

In the first hour, the model generated a rate of spread toward the north-east of approximately $4.7 \mathrm{~m} \cdot \mathrm{min}^{-1}$, which was double the rate of spread in the opposite direction (Figure 4a). During the simulation, the headfire maintained a spread rate between $4.5 \mathrm{~m} \cdot \mathrm{min}^{-1}$ and $5 \mathrm{~m} \cdot \mathrm{min}^{-1}$, indicating the greater dependence of the rate of fire spread on the magnitude of the wind speed rather than the topographical gradient. In contrast, the rate of spread into the wind reduced to 0 due to the combined effects of downslope and backfire spread. The lateral extents of the fire were constrained by heterogeneous fuels flanking the grass, since the heat produced by combustion of grass was insufficient to cause the surrounding heavy timber litter and hardwood litter to ignite. After 9.5 hours on the simulation clock (corresponding to $22 \mathrm{~h} 00$ real time), the fire extinguished, which Goodman (Goodman, 1999) attributed to dew formation resulting from a decrease in the air temperature in the late afternoon and evening. 


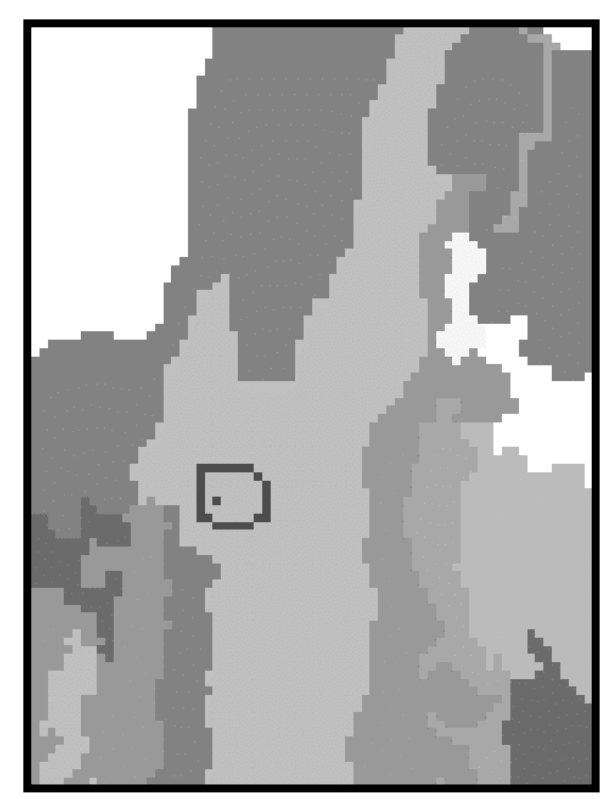

(a)

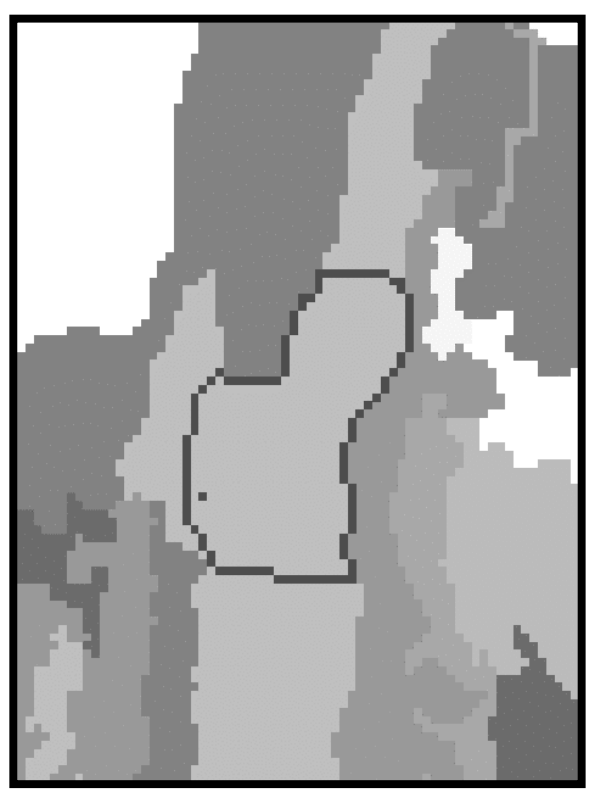

(c)

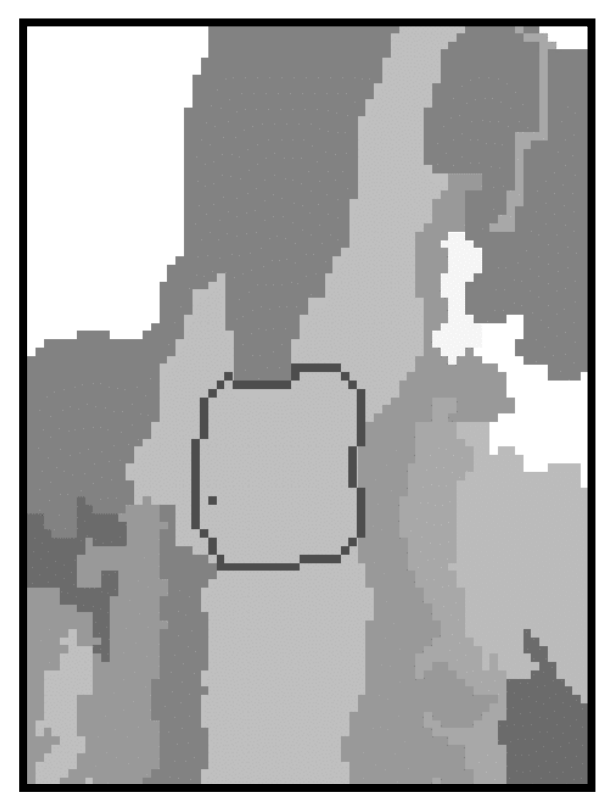

(b)

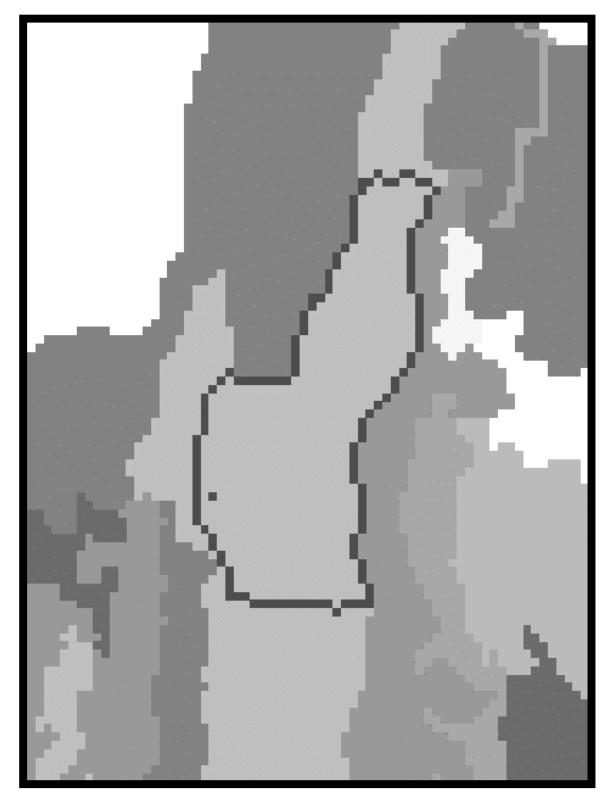

(d)

Figure 4. Fire fronts generated by the simulation model for the Mahlala area of MGR displayed after (a) 1 hour (b) 4 hours (c) 6 hours and (d) 8 hours.

In general, dew formation contributes to the plant moisture content and delays the start of fires (Luke \& McArthur, 1978). If the air temperature and hence, plaint moisture, remain constant, the fire continues to spread unabated in the north-east direction through the grass. 
To incorporate the effect of dew formation, the moisture content of the all unburned fuels were systematically raised. In particular, the moisture content of the grass was increased by $3 \%$ every 15 minutes, commencing at 8.75 hours. A further explanation for fire's extinction may be the onset of rain. This phenomenon may be implemented in a similar manner to that of dew formation, with the primary difference being an increase in the rate at which the fuel moisture content changes. However, in the event of rain, it is more probable that the raindrops extinguish flame.

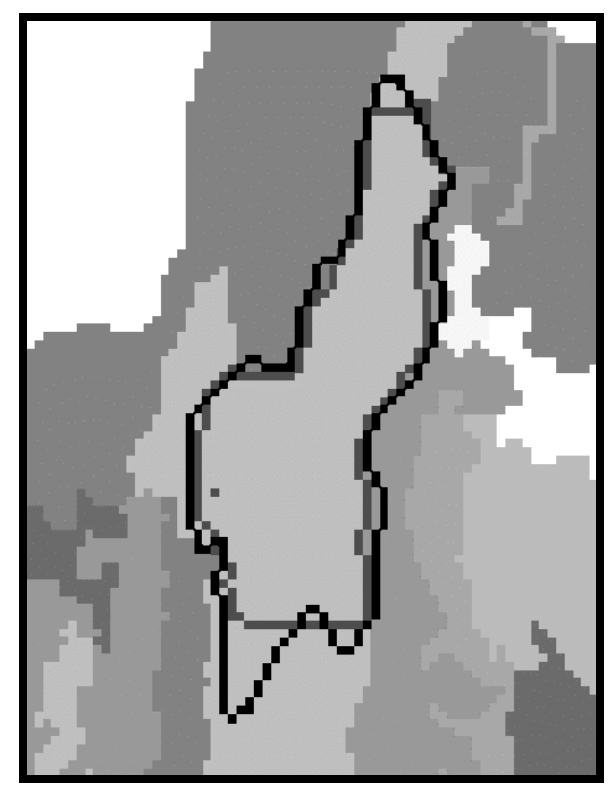

Figure 5. Fire boundary after 9.5 hours generated by the simulation model compared to the observed fire boundary (black cells) for the Mahlala area of MGR.

Figure 5 depicts the final extents of the simulated fire after 9.5 hours compared with the observed Mahlala fire boundary. Comparing areas of the predicted and observed fire boundaries showed $89 \%$ coincidence, $7 \%$ underestimation and $4 \%$ overestimation. The only significant difference between the two boundaries is the under prediction of the spread rate in the southerly direction. The observed fire boundary in this direction would appear to be related to the shape of the underlying topography. Under prediction by the simulation model may therefore be attributed to the greater influence of the prevailing wind compared to the slope angle. 


\subsection{CASE 2: TRAILS CAMP AND KHONGOLWANE FIRES}

The second case in which the model was implemented took place in the Trails Camp and Khongolwane regions of MGR. The burning operation consisted of two fires. The first was ignited in the southerly Trails Camp region at $13 \mathrm{~h} 00$ and was followed an hour later by a second fire in the northern Khongolwane region (Table 4). The duration of both fires was 6 hours, with the Trails Camp fire extinguishing at $19 \mathrm{~h} 00$ and the Khongolwane fire extinguishing an hour later.

\begin{tabular}{ccccc}
\hline Area & $\begin{array}{c}\text { Time of } \\
\text { Ignition }\end{array}$ & $\begin{array}{c}\text { Time of } \\
\text { Extinction }\end{array}$ & $\begin{array}{c}\text { Wind } \\
\text { Speed }\end{array}$ & $\begin{array}{c}\text { Wind } \\
\text { Direction }\end{array}$ \\
\hline \multirow{2}{*}{ Trails Camp } & $13 h 00$ & $19 h 00$ & $2-3$ & NE-SW \\
Khongolwane & $14 h 00$ & $20 h 00$ & $2-3$ & NE-SW \\
\hline
\end{tabular}

Table 4. Selected information from the fire record for the Trails Camp and Khongolwane regions of MGR.

In both cases the rate and pattern of fire spread was significantly influenced by the wind. In the initial stages of development, the fires spread in the presence of a light north-easterly breeze. Later on, however, the wind altered direction and increased speed resulting in a gentle south-westerly breeze. The exact time at which this occurred was not, however, recorded. 


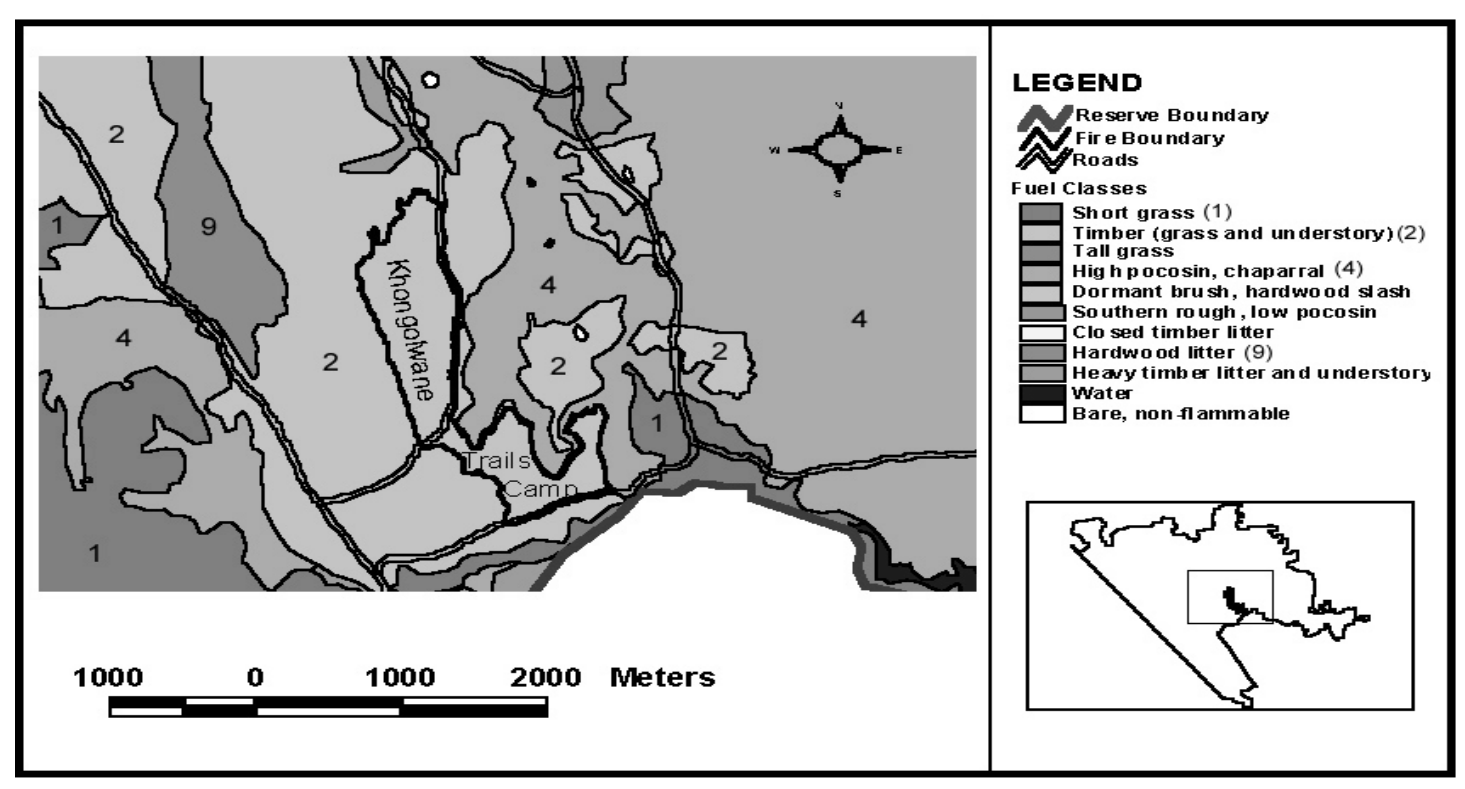

Figure 6. Map of fuel classes for the Trails Camp and Khongolwane fires

Figure 6 displays the vegetation of the region, which is dominated by grass and understory. The topography increases in a direction from east to west (Figure 7). Visual inspection of the observed fire boundary indicates that fire spread was restricted by a combination of physical and environmental factors that include wind, topography, roads and spatial heterogeneity of fuels.

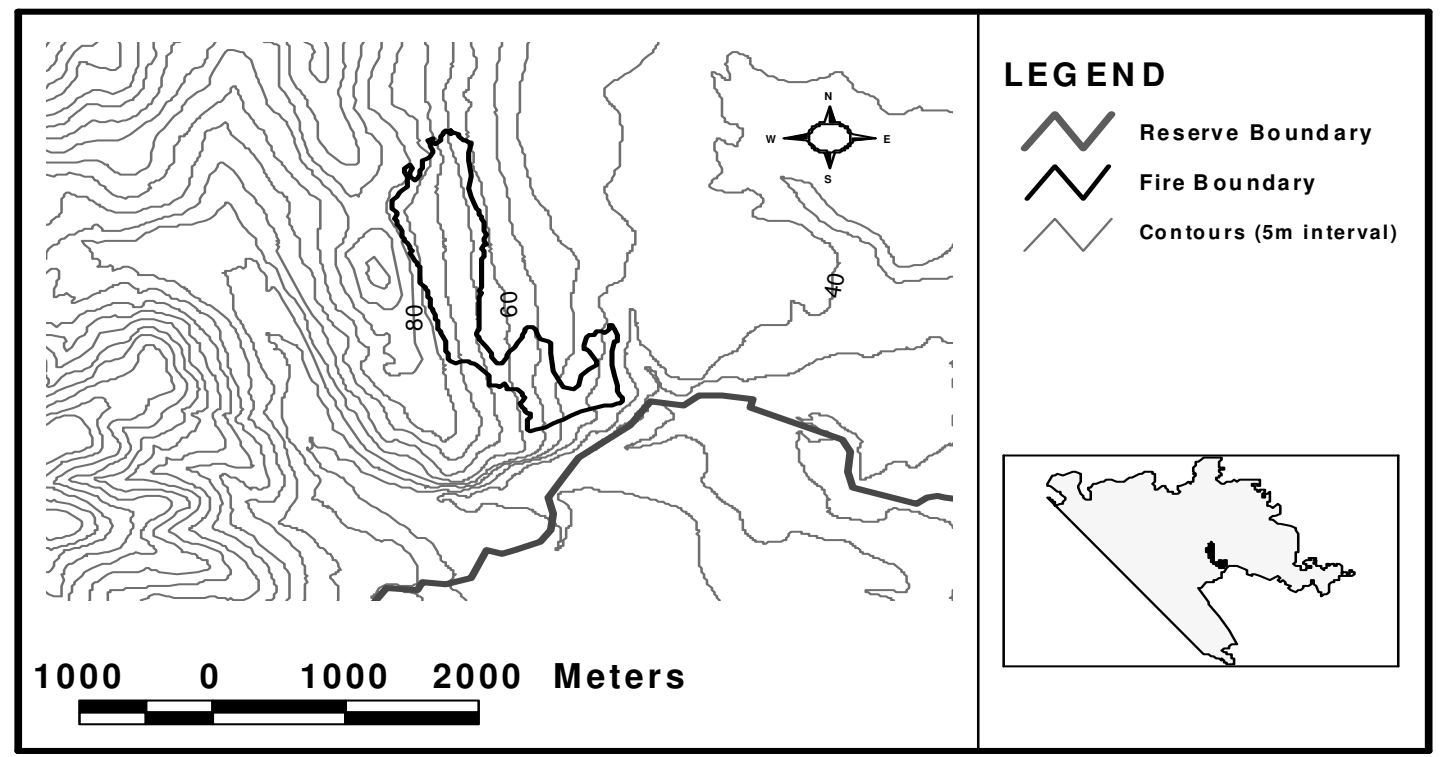

Figure 7. Map of $5 \mathrm{~m}$ contours for the Trails Camp and Khongolwane fires. 
Figure 8 is a graphical representation of the fire fronts produced by the simulation model for the Trails Camp and Khongolwane fires. Simulations were performed using a lattice with 50x50m square grid cells. The fuel moisture content for all fuels was set to $3 \%$.

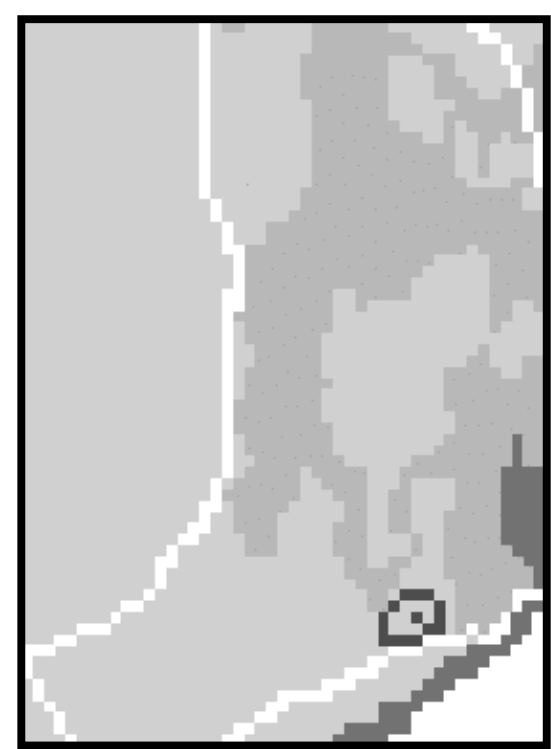

(a)

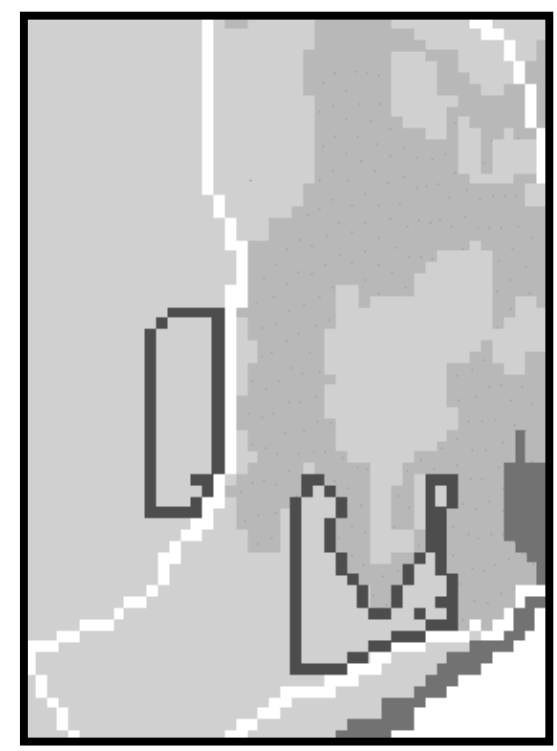

(c)

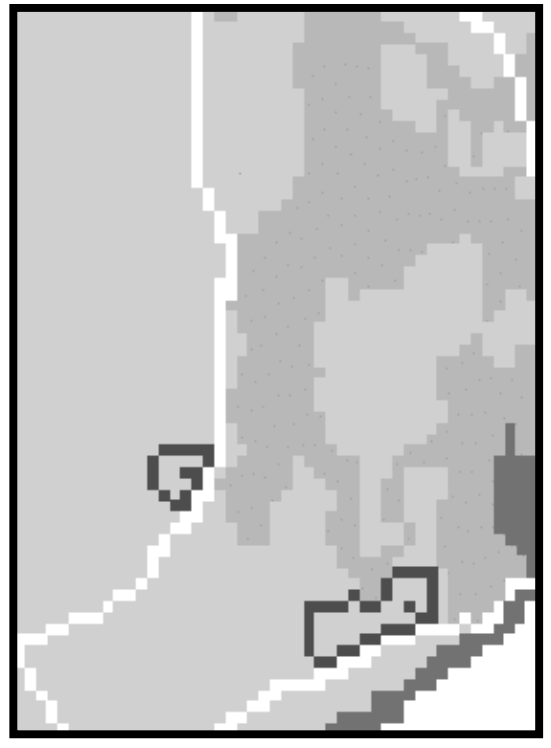

(b)

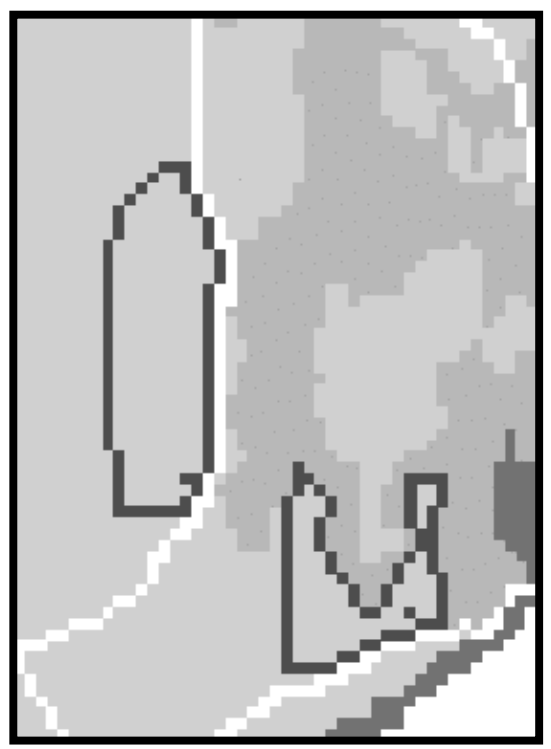

(d)

Figure 8. Fire fronts generated by the simulation model for the Trails Camp and Khongolwane areas of MGR displayed after (a) 1 hour (b) 2 hours (c) 4 hours and (d) 6 hours. 
The Trails Camp fire, illustrated in Figure 8a, was ignited in the presence of a $50 \mathrm{~m} . \mathrm{min}^{-1}$ north-easterly wind. In the first hour, the headfire progressed a distance of approximately $180 \mathrm{~m}$ at a rate of $3 \mathrm{~m} \cdot \mathrm{min}^{-1}$, whereas the rate of backfire spread was $1.86 \mathrm{~m} \cdot \mathrm{min}^{-1}$. Lateral fire spread, in the south-east and north-west directions, was restricted by the road and the high pocosin fuel respectively.

At $14 \mathrm{~h} 00$ (corresponding to one hour on the simulation clock), a fire was ignited in the Khongolwane region. In the next hour, the rate of spread in the south-west direction of the Trails Camp fire increased to $5.3 \mathrm{~m} \cdot \mathrm{min}^{-1}$, due to an increase in the topographic gradient (Figure 8b). In its first hour, the Khongolwane headfire spread a distance of approximately $160 \mathrm{~m}$ at a rate of $2.6 \mathrm{~m} \cdot \mathrm{min}^{-1}$. In contrast, the rate of backfire spread was $1.9 \mathrm{~m} \cdot \mathrm{min}^{-1}$, with the fire covering a distance of $110 \mathrm{~m}$.

After 2 hours, it was assumed that the wind switched to a $60 \mathrm{~m} \cdot \mathrm{min}^{-1}$ south-westerly. Figure $8 \mathrm{c}$ illustrates the extents of the respective fires after four hours. For both fires, the rate of spread in the northerly direction increased. The Khongolwane fire propagated at $5.4 \mathrm{~m} \cdot \mathrm{min}^{-1}$ and the Trails Camp fire at $4.6 \mathrm{~m} \cdot \mathrm{min}^{-1}$. Backfire spread in both fires did not exceed $1 \mathrm{~m} \cdot \mathrm{min}^{-1}$.

After 6 hours (corresponding to $19 \mathrm{~h} 00$ real time), the Trails Camp fire extinguished as illustrated in Figure 8d. The fire's extinction resulted from a combination of the wind shift, which reduced the intensity of backfire spread, and the restriction on lateral spread imposed by the adjacent, heterogeneous fuels. The Khongolwane fire continued to spread rapidly in the northerly direction, whilst spread rates diminished in all other directions.

One hour later, the Khongolwane fire extinguished. As was the case in the Mahlala fire, this was attributed to a reduction in the ambient air temperature and a subsequent increase in the plant moisture content. This was implemented in the simulation by increasing the fuel moisture content of the grass by $3 \%$ every 15 minutes. Figure 9 depicts the fire boundaries generated by the simulation model compared with the observed fire boundaries for the prescribed burning of the Trails Camp and Khongolwane areas. The simulated fire for the Trails Camp region was marginally underestimated, largely due to the distinct lack of backfire spread. The area of the predicted fire boundary compared with the observed fire boundary was $400000 \mathrm{~m}^{2}$ and $450000 \mathrm{~m}^{2}$ respectively, with $88 \%$ overlap, $22 \%$ underestimation and no overestimation. 


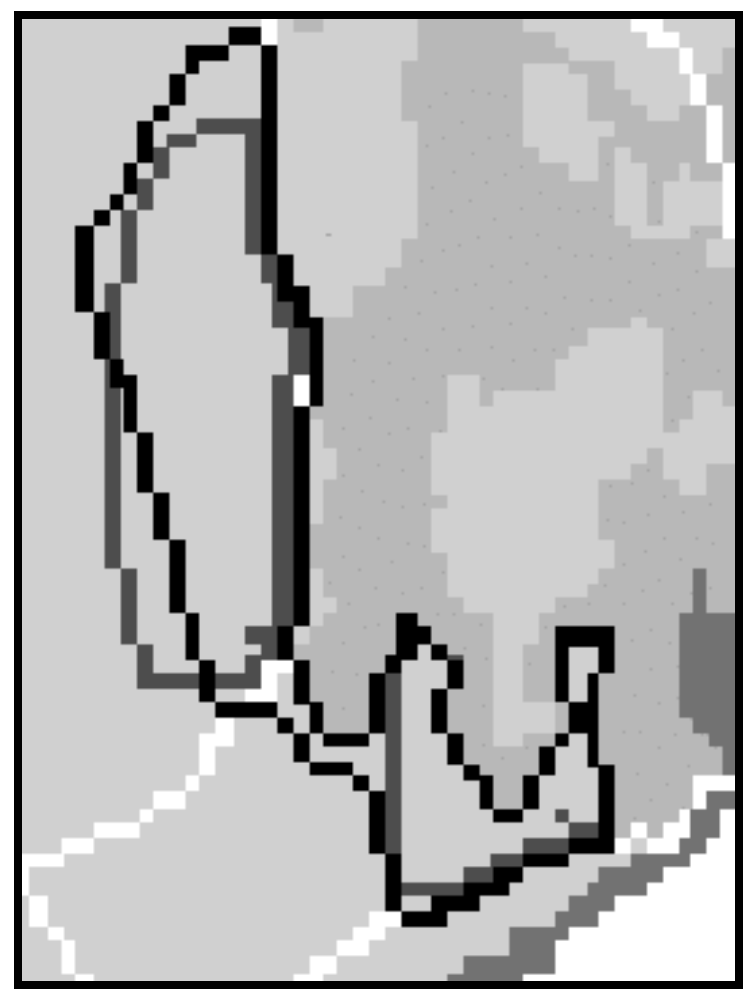

Figure 9. Fire boundaries after 7 hours generated by the simulation model compared with the observed fire boundary for the Trails Camp and Khongolwane areas of MGR.

The predicted fire boundary for the Khongolwane area overestimated the degree of spread in the westerly direction by $13 \%$, whereas the rate of spread in the northerly direction was slightly underestimated. In general, the area of the observed and predicted fire boundaries showed favourable agreement with $83 \%$ coincidence, $13 \%$ overestimation by the simulation model and only $4 \%$ underestimation.

\section{CONCLUSION}

Implementation of the spatial fire spread model revealed that it has the potential to accurately simulate spatial fire behaviour. This was illustrated in the two cases of controlled burning presented in this paper. The model, however, depends on temporal parameters such as the ambient air temperature, wind speed and wind direction, which may be difficult to estimate. In the absence of these data, various scenarios would have to be tested to establish the conditions under which a proposed burning operation would meet management objectives. With this knowledge, a manager can make an enhanced judgment on the timing of a proposed burn and hence reduce risks and increase the chance of a successful burn. 


\section{ACKNOWLEDGEMENTS}

The authors would like to acknowledge the contribution of Mr. Joe Schiller of the Satellite Application Centre (SAC) for kindly donating the Landsat TM imagery and Dr. Peter Goodman of the KZN Wildlife for his valuable input throughout the project. Funding from the South African National Research Foundation and the University of Natal is gratefully acknowledged.

\section{REFERENCES}

[1] H.E. ANDERSON, Aids to determining fuel models for fire behaviour. USDA For. Serv., Intermt. For. and Range Exp. Stn., Ogden, UT. Gen. Tech. Rep., INT-122: 22 pp (1982).

[2] S.G. BERJAK. \& J.W. HEARNE. An improved cellular automaton model for simulating fire in a spatially heterogeneous savanna system. Ecological modelling, 148(2): 133-151 (2002).

[3] W.J. BOND \& B.W. VAN WILGEN. Fire and plants. Population and Community Biology. Chapman and Hall, London. 14, 188-203 (1996).

[4] R.E. BURGAN. \& R.C. ROTHERMEL. BEHAVE: Fire behaviour prediction and fuel modelling system - Fuel subsystem. USDA For. Serv., Intermt. For. and Range Exp. Stn., Ogden, UT. Gen. Tech. Rep. INT-167: 126 pp (1984).

[5] N.P. CHENEY. Fire behaviour. In: Fire and the Australian biota. Gill, A.M., Groves, R.H. and Noble, I.R. (Eds). Australian Academy of Science, Canberra. pp 157-175 (1981).

[6] R.G. CONGALTON, K. GREEN, \& J. TEPLY. Mapping old growth forests on national forest park lands in the Pacific Northwest from remotely sensed data. Photogrammetric Engineering and Remote Sensing. 59 (4): 529-535 (1993).

[7] P.S. GOODMAN. Personal communication. Kwa-Zulu Natal Nature Conservation Services, Queen Elizabeth Park, Pietermaritzburg (1999).

[8] P.S. GOODMAN. Soil, vegetation and large herbivore relations in Mkuze Game Reserve, Natal. Unpublished $\mathrm{PhD}$ thesis, Univ. of the Witwatersrand, Johannesburg (1990).

[9] S.I. HIGGINS, W.J. BOND. \& W.S.W. TROLLOPE. Fire, resprouting and variability: a recipe for grass-tree coexistence in savanna. Journal of Ecology. 88: 213-229 (2000).

[10] R.H. LUKE. \& A.G. MCARTHUR. Bushfires in Australia. Australian Government Publishing Service. Canberra. 359 pp (1978). 
[11] R.C. ROTHERMEL. A mathematical model for predicting fire spread in wildland fuels. USDA For. Serv., Intermt For. and Range Exp. Stn, Ogden, UT. Res. Pap. INT115: $40 \mathrm{pp}$ (1972).

[12] M.W. THOMPSON. Quantitative biomass monitoring and fire severity mapping techniques in savanna environments using Landsat Thematic Mapper imagery. C.S.I.R. Div. of For. Sci. and Tech. Rep. FOR-DEA 587: 55 pp (1993).

[13] B.W. VAN WILGEN, H.C. BIGGS \& A.L.F. POTEGIETER. Fire management and research in the Kruger National Park, with suggestions on the detection of thresholds of potential concern. Koedoe. 41: 69-87 (1998).

[14] D.R. WEISE. \& G.S. BIGING. Effects of wind velocity and slope on flame properties. Can. J. For. Res. 26: 1849-1858 (1996).

[15] A.J. WILLS. The "BEHAVE" fire behaviour prediction and fuel modelling system. Unpubl., Natal Parks Board Rep. 23 pp (1987). 
